\title{
PEMBENTUKAN HUKUM YANG BERMORAL DALAM DIMENSI MEMAKNAI KEMBALI IDEOLOGI PANCASILA
}

\author{
Mohammad Hasib \\ Sekolah Tinggi Keguruan dan Ilmu Pendidikan PGRI \\ Jl. Mayor Sujadi Tim. No.24, Plosokandang, Kedungwaru \\ Kabupaten Tulungagung, Jawa Timur 66229
}

\begin{abstract}
Laws that are legitimized by the government are inclined to the year golden moral uncivilized law. Rather than aimed at authenticity and certainty in society, are laws made precisely only to protect the capitalist capitalists and the government of colle. Communities are often harmed by their constitutional rights owed to law enacted by the government. This can be seen from the banykanya accommodate of judicial review in the Constitu-tional Short which was decided with the verdict of granting either partially golden entirely. In fact, civilized and morale are always made by laws has morale institution have well. Yew in fact many laws reduce the rights of the celebrity, then it can be said that in law-makers actually doh not gaunt good morale to make the law. Pancasila have has lead star (leistar) has actually provided guidance to form has participatory and aspirational morale law through tea mechanism of deliberative democracy, tea law is called morally yew it empties and is based one tea ideology of Pancasila. Therefore it is necessary to re-actualize, re-enforce and revitalize tea ideology of Pancasila by lawmakers and for law-making institutions to produce morale law, so that tea established law can create social justice for all Indonesian celebrity.
\end{abstract}

Keyword : Pancasila, Law, Social justice

\begin{abstract}
ABSTRAK
Hukum yang dilegitimasi oleh pemerintah berkecenderungan kepada hukum yang tidak beradab atau bermoral. Alih-alih ditujukan untuk keadlian dan kepastian di masyarakat, hukum yang dibuat justru hanya untuk melindungi kaum-kaum kapitalis pemodal dan pemerintahan kolega. Masyarakat seringkali dirugikan hak-hak konstitusionalnya akibat hukum yang diundangkan pemerintah. Hal ini dapat diketahui dari banykanya perkara judicial review di Mahkamah Konstituisi yang diputus dengan amar putusan mengabulkan baik sebagian maupun seluruhnya. Padahal, hukum yang beradab dan bermoral selalu dibuat oleh lembaga yang bermoral juga. Jika nyatanya banyak hukum yang mereduksi hak- hak masyarakat, maka dapat dikatakan bahwa dalam pembentuk hukum sebenarnya tidak memiliki moral baik untuk membuat hukum. Pancasila sebagai bintang penuntun (leistar) sebenarnya telah memberikan pedoman untuk membentuk hukum yang bermoral yang partisipatif dan aspiratif melalui mekanisme demokrasi permusyawaratan, hukum disebut bermoral jika bermuara dan berlandaskan pada ideologi Pancasila. Oleh sebab itu perlu adanya reaktualisasi kembali, penghayatan kembali dan pemahamanan kembali ideologi Pancasila bari para pembentuk hukum dan bagi lembaga pembentuk hukum agar menghasilkan hukum yang bermoral, sehingga hukum yang dibentuk dapat menciptakan keadilan sosial bagi seluruh rakyat Indonesia.
\end{abstract}

Kata Kunci : Pancasila, Hukum, Keadilan sosial 


\section{A. PENDAHULUAN}

\section{Latar Belakang Masalah}

Bangsa Indonesia bangga memiliki Pancasila sebagai ideologi yang dapat mengikat seluruh masyarakat yang pluralistik majemuk dalam bingkai persatuan. Pancasila adalah konsensus nasional yang dapat diterima semua paham, golongan dan kelompok masyarakat di seluruh Indonesia dari sabang sampai merauke. Pancasila adalah dasar negara yang mempersatukan bangsa sekaligus sebagai bintang penuntun (leistar) yang senantiasa dinamis, dan mengarahkan bangsa ini pada tujuannya, sehingga dapat dikatakan juga Pancasila sebagai sumber jati diri, kepribadian, moralitas dan haluan keselamatan bangsa. Disaat negara lain mengalami krisis ideologi, bangsa Indonesia masih tetap kokoh dengan satu ideologinya yaitu Pancasila yang dinamis seiring perkembangan zaman. Atas dasar ini, maka tidaklah berlebihan jika Ir. Soekarno memandang Pancasila tidak hanya sebagai falsafah bangsa (philosofische Groundlag), namun juga sebagai pandangan dunia (weltanschauung).

Sebuah pandangan dunia yang menjadi dasar pemikiran, dasar pemikiran, dasar kerohanian, dan dasar filosofis bagi pendirian bangsa Indonesia. $^{144}$

Hukum Indonesia atau hukum Pancasila dengan pengembangan doktrinasi seperti Rule of Moral, Rule of Justice, Rule of Pancasila akan memberikan konsekwensi- konsekwensinya bagi praktik hukum di Indonesia. Suatu sisi mendasar dari doktrinasi "indonesia" tersebut sudah tercermin dalam kata-kata "moral", "keadilan", dan "Pancasila". Hal ini menandakan, bahwa lebih baik mengutamakan hati nurani daripada pemikiran atau lebih mengedepankan komitmen moral dari pada perundang-undangan.

${ }^{144}$ Weltanschauung diartikan sebagai pandangan dunia suatu masyarakat yang terbentuk dari pengalaman bersama dalam batas dan kondisi lingkungan tertentu yang menghasilkan sistem sosio kultural, khususnya nilai-nilai yang bersifat spesifik. Lihat Syaiful Arif, Falsafah Kebudayaan Pancasila, PT Gramedia Pustaka, Jakarta 2016, hlm. 33. 
Sebagai bintang penuntun (leistar) dan pandangan dunia, Pancasila harus menjadi jiwa yang mampu menginspirasi seluruh pengaturan kehidupan bermasyarakat, berbangsa dan bernegara di berbagai bidang entah itu ekonomi, politik, budaya maupun hukum. Dengan demikian, kehidupan bangsa Indonesia yang semakin kokoh apabila segenap komponen bangsa, disamping memahami juga mengamalkan Pancasila. Setiap sila Pancasila merupakan satu kesatuan yang saling berkaitan, yang saling menguatkan, saling mengejewantahkan serta saling mengunci. Ketuhanan theologi yang dijunjung tinggi sebagi dasar dalam berbangsa bernegara.

Secara yuridis ketatanegaraan, Pancasila dijadikan sebagai dasar negara Indonesia sebagaimana dalam pembukaan UUD 1945 ini merupakan hukum derajat tertinggi yang tidak dapat diubah melalui hukum positif (Pancasila sebagai anggaran dasar dan UUD 1945 sebagai anggran dasar Rumah Tangga), oleh karenanya Pancasila sebagai dasar negara memiliki kekuatan mengikat (Legally Binding) bagi seluruh penyelenggaraan kehidupan bernegara dan warga negara. Lebih dari itu, dalam basis keadaban civilitation moralitas dan haluan kebangsaan dan kenegaraan, Pancasila memiliki landasan ontologis, epistemologis dan aksiologis yang teramat kuat. Hal ini dapat dilihat ketika setiap sila memiliki justifikasi historisitas, rasionalitas dan aktualisasinya yang apabila dipahami, dihayati, dipercayai dan diamalkan secara konsisten dapat menopang pencapaian agung peradaban dunia.

\section{Rumusan Masalah}

Bagaimana pembentukan hukum yang bermoral dalam dimensi memaknai kembali Ideologi Pancasila

\section{Tujuan Penelitian}

Untuk mengkaji secara mendalam pembentukan hukum yang bermoral dalam dimensi memaknai kembali Ideologi Pancasila. 


\section{B. PEMBAHASAN}

\section{Tantangan Pembentukan Hukum}

Tantangan terbesar bangsa saat ini adalah bagaimana menjaga produk hukum yang telah dihasilkan oleh pembentuk hukum baik legislatif pusat dan daerah beserta regulasi- regulasinya dapat selaras dengan ideologi Pancasila dan tujuan negara. Mengingat Negara Indonesia memasuki abad modern ini justru semakin mengalami keterombangambingan oleh guncangan nilai-nilai dan ideologi Barat yang mereduksi segala sendi-sendi kehidupan masyarakat Indonesia. Pada kondisi ini, Pancasila sebagai ideologi bangsa telah tenggelam dalam euforia dan utopia demokrasi demokrasi kehidupan bernegara yang menjurus kepada neo liberalisme dan kapitalisme. Pengaruh nilai-nilai dan ideologi barat telah meringsek masuk dalam instrumen-instrumen hukum nasional Indonesia melalui deregulasi-deregulasi yang tampak selalu berpihak kepada kelompok kepentingan kapitalis pemodal yang bernafaskan feodalisme, sehingga seringkali dalam praktiknya menghancurkan tatanan sosial masyarakat yang telah ada dan hidup secara turun temurun. Penggunaan instrumen hukum nasional (state law) sebagai landasan legitimasi bagi para pemilik modal mengecualikan keberadaan kearifan lokal sebagai tatanan masyarakat setempat dengan melancarkan segala usahanya untuk mencapai keuntungan semata.

Kapitalisme sebagai prinsip yang menekankan pada kebebasan individu untuk saling berkompetisi sehingga menanggalkan segala akar filosofis dan sosiologisnya tidaklah sesuai dengan prinsip demokrasi ekonomi Indonesia yang berbasis pada kolektivisme. Kultur masyarakat Indonesia yang kolektivisme merupakan penggalian dari nilai-nilai budaya gotong royong yang begitu mengakar kuat dalam ruang lingkup sosiologis masyarakat Indonesia. Kapitalisme yang menekankan pada nilai individualisme telah menggerogoti sendi-sendi kehidupan masyarakat Indonesia khususnya perekonomian, padahal nilai kolektivisme masyarakat Indonesia merupakan nilai luhur yang dijadikan basis 
fundamentum dalam kehidupan berbangsa dan bernegara Indonesia. Pancasila yang terkandung di dalam Pembukaan Konstitusi adalah sebagai budaya dan jiwa bangsa Indonesia untuk hidup bersama dalam masyarakat seutuhnya.

Bahkan, Muhammad Hatta pada suatu kesempatan pernah mengatakan bahwa "soal kapital menjadi halangan besar untuk memajukan industrialisasi di Indonesia. Rakyat sendiri mempunyai kapital, kalau industrialisasi mau berarti sebagi jalan untuk mencapai kemakmuran untuk rakyat, perkataan-perkataan kemakmuran rakyat mestilah kapitalnya datang dari rakyat atau dari pihak pemerintah. Karena, kalau kapital harus didatangkan dari luar, tampak produksi terpegang oleh orang luaran." Lebih lanjut, Hatta menyebutkan bahwa motif dari kehadiran pihak asing di Indonesia semata-mata hanya untuk mencari keuntungan (profit). ${ }^{145}$

Ideologi ekonomi kapitalisme dan liberalisme tersebut memberikan ekses-ekses yang mampu menjadikan aspek-aspek untuk melakukan perubahan kehidupan sosio-kultural masyarakat. Perubahan nilai-nilai kehidupan sosial masyarakat senantiasa dipaksa dan dihadapkan untuk mengikuti segala perkembangan pesat yang terjadi dalam sistem ekonomi. Perubahan-perubahan sosial tersebut tampak dijelaskan oleh Emile Durkheim dimana masyarakat primitif memiliki kesadaran kolektif yang lebih kuat, yaitu pemahaman, norma dan kepercayaan bersama. Sedangkan kesadaran kolektif kurang signifikan dalam masyarakat yang ditopang oleh solidaritas organis daripada masyarakat yang ditopang oleh solidaritas mekanis. Masyarakat modern lebih mungkin bertahan bersama dengan pembagian kerja dan membutuhkan fungsi-fungsi yang dimiliki oleh orang lain daripada bertahan dengan kesadaran kolektif, namun dia adalah bentuk yang lemah yang tidak memungkinkan terjadinya perbedaan

${ }^{145}$ Lihat Jonker Sihombing, Peran dan Aspek Hukum dalam Pembangunan Ekonomi, Bandung: Alumni, 2010, hlm. 122 
individual. $^{146}$ Dengan demikian, untuk mengakomodasi segala kepentingan ekonomis-pragmatis-efisien dari para pemilik modal tersebut maka negara sebagai satu-satunya yang memiliki otoritas dalam hal deregulasi, administratif, dan pengendalian berupaya untuk mewadahi seala aktiitas ekonomi kapitalis-liberal tersebut dalam bentuk kebijakan hukum (legal policy) yang mana dengan dalih diharapkan mampu menciptakan suatu iklim usaha yang kondusif demi terwujudnya "kepentingan nasional" yakni "kemakmuran bersama".

Lebih jauh lagi, adanya kompromi antara kapitalis pemilik modal dengan negara mengakibatkan kebijkan-kebijkan politis negara cenderung berpihak kepada pemilik modal sehingga segala hal yang mengganggu sistem perekonomian yang berdalih dengan tujuan untuk kepentingan nasional maka dianggap sebagai pembangkangan terhadap ketertiban hukum, dengan demikian upaya represif dalam bentuk penggunaan kekerasan melalui alat- alat paksa negara Ambtenaar Besture (polisi, satpol PP dan militer) dilazimkan demi terwujudnya stabilitas perekonomian yang mampu mendukung program "kepentingan nasional" demi terwujudnya "kemakmuran bersama". Hal ini sejalan dengan pendapat salah satu tokoh aliran hukum positivistik yakni John Austin yang mana menyatakan bahwa, Law Is Command of Sovereign, dimana hukum adalah perintah atau kehendak dari penguasa yang harus dipatuhi oleh segenap anggota masyarakat. ${ }^{147}$

Negara sebagai pemegang otoritas tertinggi dalam pembuatan hukum seringkali mereduksi hukum-hukum yang berwatak budaya Pancasialis. Budaya yang sejatinya merupakan meenjadi akar identitas pembangunan hukum nasional Indonesia semakin tergerus dengan kedatangan hegemoni nilai-nilai barat yang berwatak kapitalis-liberalis sehingga kondisi ini sebagimana sejalan tesis cybernatics dari Talcott Parsons yang mengatakan bahwa budaya sebagai akar dari identitas suatu

${ }^{147}$ Andre Ata Ujan, Filsafat Hukum, Yogyakarta: Kanisisus, 2009, hlm. 70 
bangsa jika mengalami degradasi akan secara simultan menghancurkan pula segi-segi kehidupan ekonomi, sosial dan politik dari suatu masyarakat.

Hal ini apabila diakitkan dengan Pancasila sebagai dasar negara dan sebagai falsafah bangsa, tentunya akan sangat jauh bertentangan dengan gagasan sila keadilan sosial. Dalam persepktif teoritis, prinsip keadilan sosial mengandung arti keadilan yang berlaku bagi masyakarat di segala bidang hukum, sosial, politik dan kebudayaan. Lebih jauh lagi, prinsip negara harus menjamin keadilan sosial yang telah diatur secara konstitusional di dalam pasal 23,27, 28, 31, 33, 34 UUD 1945. Pasal-pasal ini menegaskan bahwa para pendiri bangsa (The Founding father"s) berkeinginan agar negara harus menguasai sumber daya alam strategis untuk kemudian dipergunakan untuk memenuhi tugas sosial negara untuk menjamin keadilan sosial warga negaranya dan bukan untuk kepantingan pemodal.

Namun sangat disayangkan, sila-sila dalam Pancasila ini masih belum dapat dihayati, diresapi serta diamalkan oleh para pembentuk hukum. Meskipun di dalam irah-irah atau konsideran undang-undang selalu mencantumkan Pancasila sebagai landasan ideal Pancasila karena justru merupakan pasal-pasal pesanan dari kapitalis pemilik modal untuk melanggengkan kekusaan dan kepentingannya. Atau dengan kata lain dapat penulis katakan bahwa banyak undang-undang berbaju Pancasila namun nafasnya kolonial. Hal ini tentunya dapat dilihat dari banyaknya undang-undang yang berkaitan dengan pengelolaan sumber daya alam Indonesia yang dibuat untuk melindungui kepentingan pemilik modal, seperti undang- undang Nomor 1 Tahun 1967 tentang Penanaman Modal Asing, Undang-undang Nomor 13 Tahun 2003 tentang Ketenaga Kerjaan, Undang-undang Nomor 7 Tahun 2004 tentang Sumber Daya Air, dan masih banyak lagi yang lainnya. 


\section{Hukum yang Bermoral}

Hukum yang bermoral atau beradab (dalam konteks hukum Indonesia) adalah hukum yang berlandaskan pada ideologi Pancasila, senafas dengan tujuan bangsa Indonesia, ia merupakan norma-norma yang terbenuk atas dasar nilai-nilai Pancasila dan ia menyentuh nilai keadilan dan kebahagiaan bagi masyarkatat. Hukum yang bermoral dibentuk oleh lembaga yang bermoral yang berjiwa Pancasilais dan telah mampu mengamalkan nilai-nilai Pancasilanya dalam kehidupan bermasyarakat, berbangsa dan bernegara. Hukum yang bermoral juga tidak saling bertentangan terutama dengan aturan yang lebih tinggi. Ia merupakan kristalisasi nilai keadilan, ketentraman dan kebahagiaan masyarakat.

Pembangunan hukum saat ini sudah seharusnya tidak hanya diarahkan untuk melahirkan produk legislasi sebanyak-banykanya melainkan juga seharusnya memasukkan nilai-nilai Pancasila dalam setiap pasal demi pasal dan norma demi norma sehingga untuk itu diperlukan manusia pemegang amanah penegakan hukum yang berkarakter dan bermoral Pancasila. Pembangunan hukum adalah pembangunan nilai-nilai kepastian hukum dan keadilan serta nilai kemanfaatannya bagi kehidupan manusia. Pembangunan hukum dan penegakannya bukan sekedar mencapai target memasukkan sebanyak-banyaknya penjahat ke dalam tahanan, melainkan juga harus dipertimbangkan dan dikritisi bagaimana penjahat- penjahat itu diperlukan berdasarkan hukum yang berlaku sampai memperoleh putusan pengadilan yang sudah berkekuatan hukum tetap (Inkrach).

Jika demikian halnya, maka menarik untuk dicermati kembali data rekapitulasi Pengujian Undang-undang (judicial riview) Mahkamah Konstitusi Tahun 2003 s/d 2016, yang disebutkan terdapat 1402 gugatan judicial riview, 865 diantarnaya telah diputus dengan rincian 196 dikabulkan, 299 di tolak, 278 tidak diterima, 92 tarik kembali dan sisanya 
masih dalam proses. ${ }^{148}$ Ini mengindikasikan dua hal: pertama, adanya semangat dan kesadaran berkonstitusi masyarakat melalui pengawasan masyarakat terhadap produk legislasi, baik sebagian maupun seluruhnya yang merugikan atau berpotensi merugikan hak konstitusional dirinya atau masyarakat lain karena bertentangan dengan hukum yang lebih tinggi (konstitusi); kedua, ini menjadi pertanda bahwa masih banyak produk legislasi yang bertentangan dengan konstitusi dan tujuan negara bahkan bertentangan dengan ideologi Pancasila. Dengan demikian, dapat dikatakann bahwa masih banyak produk hukum Indonesia yang masih belum bermoral.

Padahal, apabila merujuk teori Stufen Theorie dari Hans Kelsen, hirarki suatu aturan hukum berpuncak pada aturan yang paling dasar serta paling abstrak dan bersifat met- yuridis yang dinamakan sebagai grundnorm, sedangkan substansi hukum yang ada dalam grundnorm tersebut bukanlah berupa peraturan-peraturan melainkan nilai-nilai abstrak yang bersifat filosofis atau dengan kata lain bersubstansikan filsafat hukum yang menjiwai segala aturan hukum yang ada di bawahnya. Dari adanya konsep ini, maka tidak salah apablia Pembukaan UUD 1945 sebagai penjabaran normatif lebih lanjut dari Pancasila dikategorikan sebagai Grundnorm dalam pararelisasi konsep Stufen Theorie dari Hans Kelsen diatas terhadap struktur hirarki Tata Hukum Indonesia. ${ }^{149}$

Sepaham dengan hal itu, Hans Nawiasky juga berpandangan bahwa dalam suatu negara yang merupakan kesatuan tatanan hukum terdapat suatu kaidah tertinggi, yang kedudukannya lebih tinggi daripada undangundang dasar (konstitusi), karena berdasarkan kaidah tertinggi inilah undang-undang dasar dibentuk. Kaidah tertinggi dalam kesatuan tatanan hukum dalam negara itu disebut staats fundamental norm yang dalam

148 Lihat Rekapitulasi perkara pengujian Undang-undang MK di Website http://www.mahkamahkonstitusi.go.id/index.php?page=web. RekapPUU, diakses 15 september 2016

${ }^{149}$ Lihat Shidarta, Karakteristis Penalaran Hukum dalam Konteks Indonesia, Disertasi, Fakultas Hukum Universitas Parahyangan, Bandun, 2004, hlm. 284. 
konteks keIndonesiaan berupa Pancasila. Hakikat hukum suatu staats fundamental norm ialah syarat bagi berlakunya suatu undang-undang dasar karena lahir terlebih dahulu dan merupakan akar langsung dari kehendak sejarah suatu bangsa serta keputusan bersama yang diambil. ${ }^{150}$ Dengan demikian jelas sekali kedudukan Pancasila dalam pembentukan hukum yang bermoral, ia sebagai dasar negara, cita-cita negara, tujuan negara dan ideologi negara. Sehingga apabila suatu produk legislasi dan regulasi bertentangan dengan Pancasila, maka jelas jika itu adalah produk hukum yang tidak bermoral.

Untuk melihat dan menguji apakah suatu produk hukum bermoral ataukah tidak dapat meminjam pandangan Lon Fuller dalam bukunya The Morally of Law, diantaranya :

a. Hukum harus dipresentasikan dalam aturan-aturan umum

b. Aturan-aturan ini harus dipublikasikan kepada mereka yang menjadi objek pengaturan aturan-aturan tersebut

c. Aturan-aturan tersebut tidak boleh memiliki daya berlaku surut.

d. Aturan-aturan itu harus dirumuskan secara jelas

e. Aturan-aturan tersebut tidak boleh mengandung pertentangan

f. Aturan-aturan tersebut tidak boleh menuntut sesuatu yang tidak mungkin dipenuhi

g. Aturan- aturan itu harus kurang lebih konstan, artinya aturan itu tidak boleh terus menerus diubah

h. Pemerintah harus sebanyak mungkin berpegang teguh pada aturan ini. $^{151}$

\section{Negara Hukum Pancasila dan Demokrasi Pancasila}

Konsep negara hukum Pancasila hanya dikenal di Indonesia, hal ini dikarenakan Pancasila digunakan sebagai norma hukum tertinggi negara Indonesia. Negara hukum Pancasila bertujuan mewujudkan tata kehidupam bangsa, negara dan masyarakat yang tertib, bersih, makmur

${ }^{150}$ Lihat, Riyanto Astim, Teori Konstitusi, Yapemdo, Bandung, 2006

${ }^{151}$ Lihat Lon Fuller, The Morally of Law, Yale University Press, New Haven, 1969, hlm. 
dan berkeadilan berdasarkan Pancasila. Para pendiri bangsa (the founding father's) telah meletakkan dasar-dasar negara hukum bagi bangsa Indonesia sebagaimana telah diamnatkan di dalam pembukaan UUD 1945.

Konsep negara hukum Pancasila merupakan konsep negara hukum, yang prismatik, artinya konsep negara hukum tersebut mengintegrasikan unsur-unsur baik yang dari hal-hal yang terkandung di berbagai sistem hukum. Dengan prinsip Pancasila yang bersifat prismatik, maka diharapkan tujuan negara sebagaimna yang tercantum dalam Pembukaan UUD 1945 Alenia ke empat dapat tercapai. Hambatan- hambatan dalam pembangunan konsep negara hukum Pancasila di Indonesia, baik hambatan dari luar maupun dari dalam harus ditekan. Setiap dan semua warga negara Indonesia terlibat dalam semua lapangan kehidupan tersebut, dan karena itu wajib berpegang teguh kepada Pancasila sebai satu- satunya asas. Untuk itu, Pancasila harus dimasyarakatkan agar menjadi milik masyarakat, harus dibudayakan agar mendarah daging dalam diri manusia Indonesia, menjadi pedoman baginya dalam mengaktualisasi dirinya dalam kehidupan bermasyarakat, berbangsa dan bernegara. Sebab karena belum adanya pemasyarakatan Pancasila yang intensif dan berkesinambungan secara nasional maka pemahaman dan pelaksanaan Pancasila dalam masyarakat belum berjalan secara utuh sehingga mudah menimbulkan kesangsian serta memberi peluang masuknya ideologi lain yang bertentangan dengan Pancasila.

Dalam kaitannya dengan pembentukan hukum, sudah menjadi pengetahuan umum bahwa hukum adalah produk daripada politik, dimana ia merupakan kristalisasi, formalisasi atau legalisasi dari kehendakkehendak politik yang saling bersaingan baik melalui kompromi politik maupun melalui dominasi oleh kekuatan politik yang terbesar. Dan bukannya tidak mungkin dalam pembentukannya, pembuat hukum menyisipkan paham-paham dan ideologi yang bertentangan dengan Pancasila di setiap pasal-pasal dan norma-normanya. Pembuatan hukum (undang-undang) tidak lebih seperti hanya jual beli pasal melalui suara 
terbanyak (voting) untuk yang pihak berkepentingan. Pancasila sebenarnya telah memberikan akses jalan melalui adanya musyawarah utnuk mufakat, namun paham demokrasi yang dipakai di Indonesia adalah paham demokrasi liberal (barat) yang mengedepankan suara terbanyak daripada mufakat. Padahal sejak perumusan konstitusi, para pendiri bangsa sudah mengidealkan satu demokrasi permusyawaratan.

Baik Hatta maupun Soekarno mengidealkan sebuah demokrasi yang bertujuan untuk mencari mufakat berdasarkan sila ke empat dengan tujuan sila kelima. Bahkan Soekarno dalam suatu kesempatan menawarkan model demokrasi berupa sosio-demokrasi, yaitu demokrasi yang tidak hanya mendedahkan demokrasi politik tetapi juga demokrasi ekonomi. ${ }^{152}$ Model demokrasi ini mengakarkan sistem demokrasi diatas upaya mensejahterakan rakyat yang menurutnya selaras dengan konsep nasionalisme yang merujuk pada sosio-nasionalisme. ${ }^{153}$ Titik pandangan Soekarno ini berawal dari ketidak puasannya terhadap demokrasi barat yang hanya melahirkan demokrasi politik, yaitu hanya mengedepankan kebebasan politik kepada rakyat tetapi meminggirkan pemerataan ekonomi, bahkan hanya menguntungkan kelas borjuis.

Permusyawaratan dalam demokrasi pancasila merupakan tata cara khas kepribadian bangsa Indonesia untuk merumuskan dan memutukan suatu hal berdasar kehendak rakyat, hingga tercapai keputusan yang berdasar kebulatan pendapat atau mufakat. Selain itu, demokrasi Pancasila juga mengandung ciri "hikmat kebijaksanaan" yang merefleksikan orientasi etis. ${ }^{154}$ Orientasi etis ini dihidupkan melalui daya rasionalitas, kearifan konsensual dan komitmen keadilan yang dapat menghadirkan suatu toleransi dan sistensis yang positif sekaligus mencegah kekuasaaan yang dikendalikan oleh golongan mayoritas dan minoritas elit politik dan pengusaha.

\footnotetext{
${ }^{152}$ Lihat Syaiful Arif, Op. Cit., Hlm. 112-113

153 Ibid.

${ }^{154}$ Lihat Materi Sosialisasi Empat Pilar MPR RI, 2015, hlm. 69.
} 
Dalam demokrasi Pancasila, suara mayoritas diterima sebatas prasyarat minimum dari demokrasi yang masih harus berusaha dioptimalkan melalui partisipasi dan persetujuan yang ius dari segala kekuasaan secara inklusif yang dapat dicapai melalui persuasi, kompromi, dan konsensus secara bermutu dengan mensyaratkan mentalitas kolektif dengan bimbingan hikmat kebijaksanaan, sehingga membuat kekuatan manapun akan ikut memilki, loyal dan bertanggung jawab atas segala keputusan. ${ }^{155}$ Sehingga, voting dijadikan sebagai jalan terakhir dan itupun harus dengan menjunjung tinggi semangat kekeluargaan yang salung menghormati, karena tujuan akhir dari hikmat kebijaksanaan adalah terwujudnya keadilan sosial bagi seluruh rakyat Indonesia.

Fakta yang terjadi sekarang ini, pembuat hukum (legislatif maupun pemerintah dalam membuat regulasi) justru lebih memilih menggunakan demokrasi liberal daripada demokrasi Pancasila. Hal ini dapat dibuktikan ketika sidang paripurna, ketika terjadi deadlock mereka lebih memilih menggunakan suara mayoritas. Terlebih lagi, ketika yang dibahas adalah Undang-undang yang berkaitan dengan pengelolaan sumber daya alam atau yang menguasai hajat hidup orang banyak dan sekiranya dapat dijadikan mega proyek bagi kelompok tertentu, maka mereka akan sekuat tenaga mempertahankan ego pendapatnya.

Demi kepentingan segelintir orang, mereka melupakan amanat konstitusi dalam mencapai keadilan sosial bagi seluruh rakyat Indonesia. Fakta menarik lainnya, sikap pembuat Undang- undang juga patut dipertanyakan dalam membuat kebijakan-kebijakan yang bermoral. Seperti misalnya pada saat penentuan APBN-P atau pada saat mengesahkan kebijakan kenaikan harga BBM. Mereka baik di pihak pro maupun kontra rela meninggalkan moral Pancasilaisnya demi ego golongan. Bahkan tidak sedikit diantaranya berakhir ricuh dengan hujan interupsi, membuat kegaduhan/perkelahian, saling melempar kursi, menyembunyikan palu 
pimpinan sidang, bahkan hingga terjadi walkout dari sidang. Ini adalah sebagian kecil dari dampak dianutnya demokrasi liberal dan mengesampingkan demokrasi Pancasila yang notabene adalah tradisi dan warisan asli Indonesia.

Menariknya, gagasan demokrasi permusyawaratan atau demokrasi Pancasila yang merupakan asli warisan bangsa Indonesia ini hampir sama dengan gagasan demokrasi deliberatif dari seorang filsuf Jerman bernama Jurgen Habermas. Bagi Habermas, demokrasi deliberatif adalah konsep demokrasi yang mendasarkan diri pada mekanisme musyawarah yang mendalam. Oleh karena itu, demokrasi deliberatif adalah demokrasi yang menggunakan musyawarah dalam mekanisme demokrasinya. Lahirnya demokrasi liberatif dilandasi oleh kegelisahan Habermas terhadap demokrasi modern yang hanya menggunakan prinsip majoritarianisme dalam melegitimasi setiap kebiajakan maupun perundang-undangan. Oleh sebab itu, Habermas mencoba membangun konsep deliberatif agar dapat membentuk masyarakat politik yang komunikatif yang menggunakan setiap akal budinya dalam politik yang bagi Habermas telah menjadi persoalan mendasar dalam masyarakat modern. Padahal, apabila dalam sejarah Keindonesiaan, demokrasi deliberatifnya Habermas sudah diterapkan di Indonesia sejak ratusan tahun yang lalu. ${ }^{156}$

\section{PENUTUP}

\section{Kesimpulan}

Memaknai Kembali Pancasila berarti bahwa kita ingin menegaskan komitmen bahwa nilai-nilai Pancasila adalah dasar dan ideologi dalam bermasyarakat, berbangsa, dan bernegara. Pancasila bukan konsep

156 Menurut Hatta, demokrasi Pancasila adalah demokrasi asli Indonesia untuk mencari mufakat dalam kerangka hikmat kebijaksanaan dan berujung pada perwujudan keadailan sosial. Dengan merujuk pada praktik demokrasi desa, seperti rapat mencari mufakat, kepemilikan tanah secara bersama, gotong royong, serta protes rakyat atas kebijkan raja, Hatta memberikan dasar historis kultural bagi pribumisasi demokrasi. Lihat Zulkifri Suleman, Demokrasi Untuk Indonesia, Pemikiran Politik Bung Hatta, Kompas, Jakarta, 2010, hlm. 181- 185. 
pemikiran semata, namun sebagai perangkat tata nilai untuk diwujudkan sebagai panduan dalam berbagai segi kehidupan. Dengan demikian nilai Pancasila menjadi landasan etika dan moral ketika hendak membangun pranata politik, pemerintahan, ekonomi, dan penegakan hukum (law enforcement).

Seperti sudah penulis jelaskan diatas, bahwa hukum adalah produk daripada politik. Didalamnya sarat dengan muatan politik yang dibawa oleh golongan dan partai. Undang-undang adalah kepanjangan tangan dari parlemen yang penuh dengan kepentingan- kepentingan politis para anggotanya. Sehingga, tidak dengan sendirinya suatu undang-undangyang dibuat oleh parlemen dapat betul-betul menyuarakan aspirasi kehendak dan kebutuhan rakyat. Sudah penulis jelaskan juga bahwa hukum/undangundang yang bermoral dihasilkan oleh lembaga yang bermoral juga, atau lembaga yang bermoral pastilah menghasilkan hukum/undang-undang yang bermoral yang masing-masing anggotanya harus bermoral dan berakal budi Pancasilais.

Reaktualisasi disini diartikan sebagai aktualisasi kembali, penghayatan kembali dan pemahaman kembali ideologi Pancasila bagi para pembentuk hukum dan bagi lembaga pembentuk hukum agar menghasilkan hukum yang bermoral, sehingga mampu menghasilkan keadilan sosial bagi seluruh rakyat Indonesia. Meminjam tesis sistem hukum dari Lawrance Friedmann dalam bukunya The Legal System, menyebutkan bahwa efektif dan berhasilnya penegakan hukum tergantung tiga unsur sistem hukum, yaitu struktur hukum (legal structure), substansi hukum (legal substance) dan budaya hukum (legal culture). Oleh sebab itu, aktualisasi ideologi Pancasila dalam pembentukan hukum yang bermoral juga tidak dapat dipisahkan dari ketiga sistem hukum tersebut.

Pertama, struktur hukum terdiri dari perngkat-perangkat hukum pada arti yang luas, yaitu mengarah pada lembaga-lembaga Legislatif, Eksekutif dan Yudikatif (termasuk ddalamnya adalah anggota-anggotanya). Lembaga yang bermoral menghasilkan hukum yang bermoral, oleh sebab itu 
aktualisasi Pancasila dalam struktur hukum adalah bagaimana mereka mampu memahami Pancasila dan mengamalkannya dalam kehidupan berbangsa dan bernegara, bagaimana pejabat negara dan perjabat pemerintahan mematuhi hukum dengan benar, bagaimana model perekrutan anggota yang nantinya menjabati posisi-posisi dari struktur hukum tersebut, dan bagaimana mereka merumuskan kebijakan/hukum yang memenuhi rasa keadilan dan kepastian serta tidak menimbulkan diskriminasi. Setiap pejabat/ orang yang ada dalam struktur hukum harus memiliki jiwa pancasialis yang tertanam dalam akal budi dan hati mereka.

Struktur-struktur hukum memainkan peranan penting dalam membentuk hukum yang bermoral Pancasila. Diperlukan adanya pengajar hukum yang berjiwa Pancasilais sehingga menghasilkan jurist yang berpancasialis juga, diperlukan parlemen yang berpancasilis, jaksa yang berpancasialis, hakim yang berpancasialis dan sebaginya. Sehingga tidak memunculkan sikap mental "wani piro" dalam setiap penegakan hukum (law enforcement) yang pada akhirnya merugikan masyarakat.

Kedua. Substansi hukum terbentuk ketika struktur hukum sudah baik dan bermoral dalam hal ini sudah mengaktualisasikan Pancasila dalam kehidupannya. Substansi hukum ini nantinya diarahkan pada peraturan, pasal-pasal, norma-norma, dan perilaku masyarakat. Jika kaidah pertama sudah terpenuhi (struktur sudah bermoral), maka pastilah substansi hukum juga bermoral. Hukum yang bermoral di hasilkan oleh proses yang bermoral yaitu harus melepaskan segala bentuk macam kepentingan politis dalam pembentukan hukum dan bermuara pada satu tujuan yaitu keadilan sosial. Jika dikaitkan dengan moral Pancasila, maka substansi hukum yang bermoral dihasilkan melalui proses demokrasi permusyawaratan untuk mufakat.

Ketiga, budaya hukum dapat ditinjau dari sikap masyarakat, kepercayaan masyarakat, nilai-nilai yang dianut oleh masyarakat dan citacita yang diharapkan masyarakat pada hukum. Budaya hukum ini nantinya merupakan gambaran dari perilaku masyarakat terhadap hukum, sehingga 
semakin tinggi kesadaran hukum masyarakat maka tercipta budaya hukum yang baik dan tercipta kepatuhan hukum yang baik oleh masyarakat. Artinya, budaya hukum tidak akan tercipta tanpa adanya struktur dan substansi hukum yang baik, sehingga dengan adanya struktur hukum yang pancasilais menciptakan substansi hukum yang bermoral dan pada akhirnya menciptakan budaya hukum Pancasila.

Seperti telah dijelaskan diatas bawa ideologi bangsa Indonesia adalah Pancasila, dasar negara Indonesia adalah Pancasila. Apabila ketika sistem diatas sudah berpancasila maka tujuan negara sebagimana dicitacitakan oleh pendiri bangsa dapat tercapai. Pancasilatidak hanya sebagai penuntun (leistar) bagi masyarakat Indonesia dalam kehidupan berbangsa dan bernegara, melainkan juga sebagai pandangan dunia. 


\section{DAFTAR PUSTAKA}

\section{A. Literatur}

Andre Ata Ujan. 2009. Filsafat Hukum, Yogyakarta : Kanisius

As'ad Said Ali. 2009. Negara Pancasila, Jalan Kemaslahatan Bangsa. Jakarta : LP3ES

F. Budi Hardiman. 2009. Demokrasi Deliberatif, Menimbang Negara Hukum dan Ruang Publik dalam Teori Diskursus Jurgen Habermas. Yogyakarta : Kanisius

Jonker Sihombing. 2010. Peran dan Aspek Hukum dalam Pembangunan Ekonomi. Bandung : Aumni

Jurgen Habermas. 2008. Ruang Publik, Sebuah Kajian Tentang Kategori Masyarakat Borjuis (penerjemah Yudi Santoso). Yogyakarta : Kreasi Wacana

Lin Fuller. 1969. The Morally of Law. New Haven : Yale University Press Majelis Permusyawaratan Rakyat Republik Indonesia. 2015. Materi Sosialisasi Empat Pilar Kehidupan Berbangsa dan Bernegara. Jakarta : MPR RI

Riyanto Astim. 2006. Teori Konstitusi. Bandung : Yapemdo

Shidarta. 2004. Karakteristik Penalaran Hukum dalam Konteks Indonesia. Disertasi. Bandung : Fakultas Hukum Universitas Parahyangan

Syaiful Arif. 2006. Falsafah Kebudayaan Pancasila. Jakarta : PT Gramedia Pustaka

Yudi Latief. 2011. Negara Paripurna, Historisitas, Rasionalitas dan Aktualitas Pancasila. Jakarta : Gramedia Pustaka Utama 